Бондарєва Т. Г., к.е.н., доцент (Національний університет водного господарства та природокористування, м. Рівне), Немкович О. Б., к.е.н. (Відокремлений структурний підрозділ «Рівненський коледж Національного університету біоресурсів і природокористування України» м. Рівне, Україна)

\title{
СУЧАСНИЙ СТАН ПРАВОВОГО ЗАБЕЗПЕЧЕННЯ ЗДІЙСНЕННЯ ВАЛЮТНИХ ОПЕРАЦІЙ СУБ'ЄКТАМИ ЗОВНІШНЬОЕКОНОМІЧНОЇ ДІЯЛЬНОСТІ
}

У статті розкрито основні недоліки діючої системи валютного регулювання. Виявлено стійку тенденцію до відтоку валютних цінностей за межі України через неповернення їх суб'єктами зовнішньоекономічних відносин при здійсненні експортно-імпортних операцій та погіршення стану розрахунків в іноземній валюті в Україні. Здійснено характеристику основних нормативно-правових актів, які лягають в основу нової системи валютного регулювання. Виділено ключові новації у сфері валютних відносин. Наголошено на необхідності послідовного проведення валютної лібералізації, оскільки швидка її реалізація може призвести до макроекономічних ускладнень.

Ключові слова: валютне регулювання, валютне законодавство, валютні операції, зовнішньоекономічні відносини, суб'єкти зовнішньоекономічної діяльності.

Постановка проблеми в загальному вигляді. Однією з основних проблем, яка існує сьогодні у сфері ведення зовнішньоекономічної діяльності $\epsilon$ низька ефективність чинного валютного законодавства. Діюча нормативно-правова база, що регулює валютні відносини $\epsilon$ недосконалою, обтяжливою, необґрунтовано створює протиріччя у регулюванні таких відносин, що несе загрозу фінансовій стабільності держави, зокрема призводить до знецінення дестабілізації валюти та відтоку валютних цінностей. Тому надзвичайно важливим $є$ дослідження питань, пов'язаних із формуванням та реалізацією єдиної державної валютної політики шляхом впровадження удосконаленого режиму валютного регулювання.

Аналіз останніх досліджень і публікацій. Дослідженню проблем регулювання валютної сфери України загалом, та лібералізації валютного регулювання зокрема присвячені наукові праці Я. Белін- 
ської, О. Береславської, О. Боришкевича, А. Гальчинського, А. Гриценка, А. Даниленка, М. Єршова, Т. Ковальчука, В. Козюка, С. Корабліна, Т. Кричевської, А. Кузнєцова, О. Петрика, І. Співака, В. Міщенка, Т. Унковської, О. Шарова, С. Шумської та ін. В той же час, незважаючи на численні надбання теоретичного та практичного характеру в сфері дослідження лібералізації валютного регулювання, окремі питання, зокрема, що стосуються валютних операцій на здійснення яких з правової точки зору вплине функціонування нового закону «Про валюту і валютні операції» $€$ недостатньо розкритими у науковій літературі.

Формулювання цілей статті. Метою статті $€$ дослідження та аналіз валютного законодавства України та виділення ключових новацій ліберальної системи валютного регулювання.

Виклад основного матеріалу дослідження. За даними Державної служби статистики України у 2017 р. обсяг експортних операцій склав 43264,7 млн дол. США, імпортних операцій - 49607,2 млн дол. США [1].

Кількість підприємств-експортерів, що здійснювали у 2017 р. зовнішньоекономічну торгівлю товарами становила в експорті 16,5 тис., в імпорті - 27,1 тис. [2, С. 18]. Водночас кількість зареєстрованих осіб, які здійснюють операції з товарами, станом на 01.04.2018 становила 105,7 тис. осіб (у тому числі 84,5 тис. - юридичних осіб і 21,2 тис. - фізичних осіб-підприємців), що значно перевищує кількість осіб, які фактично здійснювали впродовж року операції з товарами. Така розбіжність пояснюється тим, що встановити точну кількість осіб, які фактично здійснювали у 2017 р. експортно-імпортні операції неможливо, оскільки вони могли бути експортерами та імпортерами товарів одночасно.

Разом з тим, є можливим вступ у зовнішньоекономічні відносини і негосподарюючих суб'єктів, які здійснюють окремі зовнішньоекономічні операції в порядку господарчого забезпечення їх основної діяльності, фізичних осіб, які не є підприємцями, але спільно з іноземними партнерами виступають засновниками (учасниками) підприємств корпоративного типу, зокрема придбавають цінні папери іноземних емітентів, передають за договорами іноземним суб'єктам господарської діяльності (СГД) права інтелектуальної власності. При цьому їх неможливо визнати суб'єктами зовнішньоекономічної діяльності (ЗЕД) [3].

На жаль, наразі спостерігається стійка тенденція до відтоку валютних цінностей за межі України через неповернення їх суб'єктами зовнішньоекономічних відносин при здійсненні експортно-імпортних операцій. Стан розрахунків в іноземній валюті в Україні погіршуєть- 
ся. Так заборгованість іноземних СГД перед суб'єктами ЗЕД вародовж 2016-2017 рр. за експортними операціями в доларовому еквіваленті зросла у 1,8 разів (у тому числі безнадійна - 2,4 рази); за імпортними операціями прострочена заборгованість зменшилась на 18,9\% (1 млрд дол. США), проте безнадійна - зросла у 1,5 разів (з 2,1 до 3,2 млрд дол. США) [3].

Зазначене великою мірою спричинене недосконалістю діючої системи валютного регулювання, яка $є$ нормативно неврегульованою та неефективною.

Зауважимо, що на даний час чинна база у сфері валютного регулювання включає 56 нормативно-правових актів, що безпосередньо чи опосередковано визначають порядок здійснення валютних операцій і встановлюють певні обмеження. Основними з них є Закон України від 23.09.1994 № 185 «Про порядок здійснення розрахунків в іноземній валюті» та Декрет КМУ від 19.02.1993 № 15-93 «Про систему валютного регулювання і валютного контролю», які регламентують режим здійснення валютних операцій на території України, загальні принципи валютного регулювання, повноваження державних органів і функції банків та інших фінансових установ України в регулюванні валютних операцій, права й обов'язки суб'єктів валютних відносин, порядок здійснення валютного контролю, відповідальність за порушення валютного законодавства [4; 5].

Проте суперечливі норми діючого законодавства, відсутність механізмів і порядків щодо забезпечення належного контролю за дотримання суб'єктами зовнішньоекономічної діяльності валютного законодавства, ефективної взаємодії та інформаційного співробітництва між державними органами, уповноваженими на його здійснення, сприяли низькій конкурентоспроможності суб'єктів зовнішньоекономічних відносин на зовнішніх ринках товарів і послуг.

3 метою удосконалення законодавчої бази, приведення у відповідність з європейськими практиками про вільне переміщення капіталу, створення сприятливих умов для інвестування капіталу в українську економіку та міжнародних відносин, запроваджено заходи з лібералізації діючої системи валютного регулювання. Спільними зусиллями Національного банку України (НБУ), Міністерством фінансів, Державною фіскальною службою і Міністерством економічного розвитку і торгівлі України розроблений та затверджений покроковий механізм і порядок забезпечення валютного регулювання.

На сьогодні підготовлено низку законопроектів, направлених на забезпечення реалізації єдиної державної валютної політики, вільного здійснення валютних операцій на території України та вільно- 
го руху валютних цінностей при проведенні цих операцій між резидентами і нерезидентами.

Основою для нової системи валютного регулювання став Закон України від 21.06.2018 р. № 2473-VIII «Про валюту і валютні операції», а також проекти постанов НБУ, які включають 7 основних нормативно-правових актів, що деталізують правила роботи банків (рисунок).

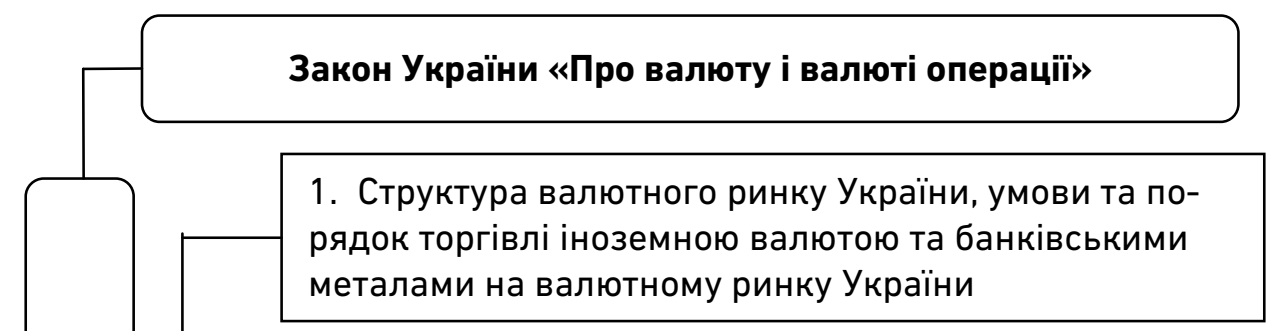

2. Порядок розрахунків, операцій з купівлі та переказів іноземної валюти на території України та за

3. Транскордонне переміщення готівкової національної та іноземної валюти, банківських металів, а також цінних паперів в документарній формі банками, юридичними та фізичними особами

4. Загальний перелік заходів захисту для можливого застосування Національним банком, критерії і порядок їх запровадження, умови їх подовження та дострокового припинення

5. Перелік запроваджених заходів захисту та порядок їх застосування (антикризова постанова, що має тимчасовий характер)

6. Інші інструменти стабілізації грошово-кредитного ринку (резервування за валютними операціями), а також повідомлювальну систему збору інформації про валютні операції

7. Порядок дотримання граничних строків розрахунків, встановлених Національним банком

Рисунок. Проект структури валютного регулювання

Щодо постанов, зазначених на рис. 1, то перші три з них містять норми валютного регулювання, які почнуть діяти при повному переході 
України до свободи проведення валютних операцій, які передбачені Законом «Про валюту і валютні операції», тобто, частково вони застосовуватимуться із 07.02.2019 р., а за сприятливих макроекономічних умов запрацюють повною мірою на постійній основі.

До настання сприятливих макроекономічних умов валютне регулювання також буде частково здійснюватися в рамках тимчасових постанов № 5-7. Також передбачається запровадження тимчасової постанови №4 для захисту економіки і фінансової системи у випадках кризових макрофінансових ситуацій. При стабілізації макроекономічного стану тимчасові акти припинять свою дію, а валютне регулювання здійснюватиметься за нормами постійних актів.

Акцентуємо увагу на ключових новаціях нової системи валютного регулювання (рис. 2).

Слід наголосити, що лібералізація валютної політики тягне за собою зміни в законодавстві. Так КМУ спільно з НБУ необхідно розробити та внести на розгляд ВРУ законопроекти щодо здійснення одноразового декларування активів фізичних осіб та про міжнародну співпрацю України в галузі оподаткування, що визначатимуть: правила оподаткування контрольованих іноземних компаній; правила звітності в розрізі країн для міжнародних груп компаній; правила обмеження витрат на фінансові операції з пов'язаними особами; правила оподаткування постійного представництва; заходи щодо запобігання зловживанням у зв'язку із застосуванням договорів про уникнення подвійного оподаткування; процедуру врегулювання спорів з питань застосування конвенцій про уникнення подвійного оподаткування; питання впровадження міжнародних стандартів для автоматичного обміну фінансовою інформацією [4].

Погоджуємося з думкою фахівців, що надзвичайно важливим у процесі проведення валютної лібералізації $€$ послідовний підхід, оскільки швидка їі реалізація може призвести до макроекономічних ускладнень, зокрема відтоку валютних коштів з України, переважання попиту на іноземну валюту, що створить ризики цінової та фінансової нестабільності.

Висновки. Таким чином, нова система валютного регулювання забезпечить встановлення режиму валютного регулювання, який передбачає вільне проведення валютних операцій їх суб'єктами, спрощення проведення таких операцій, покращення інвестиційного клімату та інвестиційної привабливості України. 


\begin{tabular}{|c|}
\hline Скасовується \\
\hline $\begin{array}{l}\checkmark \text { валютний нагляд для експортно-імпортних операцій до } 150 \text { тис. } \\
\text { грн.; } \\
\checkmark \text { індивідуальні ліцензії на валютні операції; } \\
\checkmark \text { санкції у вигляді припинення зовнішньоекономічної діяльності; } \\
\checkmark \text { ліміт на дострокове погашення зовнішніх зобов'язань; } \\
\checkmark \text { реєстрація зовнішніх запозичень; } \\
\checkmark \text { подвійний контроль операцій під час надходження митної де- } \\
\text { кларації до іншого банку }\end{array}$ \\
\hline Дозволяється \\
\hline $\begin{array}{l}\checkmark \text { вільне відкриття рахунків юридичних осіб за кордоном; } \\
\checkmark \text { розрахунки в іноземній валюті за валютними державними облі- } \\
\text { гаціями; } \\
\checkmark \text { валютні свопи банків з резидентами та нерезидентами; } \\
\checkmark \text { безпоставочні форварди та форварди для хеджування боргових } \\
\text { операцій; } \\
\checkmark \text { ввезення-вивезення готівкової іноземної валюти та банківських } \\
\text { металів юридичними особами; } \\
\checkmark \text { внесення платежів у іноземній валюті під час страхування жит- } \\
\text { тя; } \\
\checkmark \\
\text { накопичення валюти на рахунках юридичних осіб для погашен- } \\
\text { ня зовнішніх запозичень; } \\
\checkmark \text { безлімітні інвестиції банків в цінні папери інвестиційного класу; } \\
\checkmark \text { інвестиції та кредитування резидентів з гривневих ЛоРо- } \\
\quad \text { рахунків банків-нерезидентів; } \\
\checkmark \text { інвестиції в Україну також у валютах 2-ї групи класифікатора } \\
\text { валют }\end{array}$ \\
\hline Збільшується \\
\hline $\begin{array}{l}\checkmark \text { граничний строк здійснення розрахунків за експортно- } \\
\text { імпортними контрактами - до } 365 \text { днів; } \\
\checkmark \text { ліміт на перекази за кордон без відкриття рахунку для фізичних } \\
\text { осіб в } 10 \text { разів до } 150 \text { тис. грн/рік; } \\
\checkmark \text { ліміт на купівлю банківських металів фізичними особами та } \\
\text { юридичними особами з 3,21 тр. унції на тиждень (100 г) до екві- } \\
\text { валенту } 150 \text { тис. грн/день - без обмежень для спеціалізованих } \\
\text { юридичних осіб }\end{array}$ \\
\hline Спрощується \\
\hline $\begin{array}{l}\checkmark \text { здійснення операцій за рахунками юридичних осіб- } \\
\text { нерезидентів у банках України; } \\
\checkmark \text { переміщення валютних цінностей через кордон - уніфіковано } \\
\text { обов'язкове декларування для всіх цінностей вартістю від } \\
10 \text { тис. євро }\end{array}$ \\
\hline
\end{tabular}

Рис. 2. Нововведення системи валютного регулювання [6] 
1. Державна служба статистики України / ред. І. Є. Вернера. Україна у цифpax 2017 рік : статистичний збірник. К., 2018. 240 с. 2. Державна служба статистики України / відп. за випуск. А. О. Фризоренко. Зовнішня торгівля України товарами та послугами 2017 рік : статистичний збірник. К., 2018. 147 с. 3. Звіт про результати аудиту ефективності виконання повноважень державними органами щодо забезпечення контролю за дотриманням суб'єктами зовнішньоекономічної діяльності вимог валютного законодавства : Затверджено рішенням Рахункової палати від 26.06.2018 № 15-5. / URL: http://www.ac-rada.gov.ua/doccatalog/document/16757250/zvit_15-5. (дата звернення: 07.04.2019). 4. Про валюту і валюті операції : Закон України від 21.06.2018 р. № 2473-VIII. URL: https://zakon.rada.gov.ua/laws/show/2473-19. (дата звернення: 15.05.2019). 5. Про систему валютного регулювання і валютного контролю : Декретом Кабінету Міністрів України від 19.02.1993 № 15-93. URL: https://zakon.rada.gov.ua/laws/show/15-93. (дата звернення: 15.05.2019). 6. Офіційне Інтернет-представництво НБУ : Валютне регулювання поновому: проекти від Нацбанку. URL: https://bank.gov.ua/control/uk/publish/article?art_id=81262307. Назва з екрану. (дата звернення: 15.05.2019).

\section{REFERENCES:}

1. Derzhavna sluzhba statystyky Ukrainy / red. I. Ye. Vernera. Ukraina u tsyfrakh 2017 rik : statystychnyi zbirnyk. K., 2018. 240 s. 2. Derzhavna sluzhba statystyky Ukrainy / vidp. za vypusk. A. 0. Fryzorenko. Zovnishnia torhivlia Ukrainy tovaramy ta posluhamy 2017 rik : statystychnyi zbirnyk. K., 2018. 147 s. 3. Zvit pro rezultaty audytu efektyvnosti vykonannia povnovazhen derzhavnymy orhanamy shchodo zabezpechennia kontroliu za dotrymanniam subiektamy zovnishnoekonomichnoi diialnosti vymoh valiutnoho zakonodavstva : Zatverdzheno rishenniam Rakhunkovoi palaty vid 26.06.2018 № 15-5. URL: http://www.ac-rada.gov.ua/doccatalog/document/16757250/zvit_15-5. (data zvernennia: 07.04.2019). 4. Pro valiutu i valiuti operatsii : Zakon Ukrainy $\begin{array}{lllll}\text { vid 21.06.2018 } \quad \text { r. } & \text { № 2473-VIII. URL: }\end{array}$ https://zakon.rada.gov.ua/laws/show/2473-19. (data zvernennia: 15.05.2019). 5. Pro systemu valiutnoho rehuliuvannia i valiutnoho kontroliu : Dekretom Kabinetu Ministriv Ukrainy vid 19.02.1993 № 15-93. URL: https://zakon.rada.gov.ua/laws/show/15-93. (data zvernennia: 15.05.2019). 6. Ofitsiine Internet-predstavnytstvo NBU : Valiutne rehuliuvannia ponovomu: proekty vid Natsbanku. URL: https://bank.gov.ua/control/uk/publish/article?art_id=81262307. Nazva z ekranu (data zvernennia: 15.05.2019).

Рецензент: д.е.н., доцент Осадча О. О. (НУВГП) 
Bondarieva T. H., Candidate of Economics (Ph.D.), Associate Professor (National University of Water and Environmental Engineering, Rivne), Nemkovych O. B., Candidate of Economics (Ph.D.) (Rivne College of National University of Life and Environmental Sciences of Ukraine, Rivne)

\section{THE CURRENT STATE OF LEGAL SUPPLY OF EXCHANGE OPERATIONS CONDUCTED BY SUBJECTS OF FOREIGN ECONOMIC ACTIVITY}

This article is devoted to the analysis of Ukrainian currency legislation. The main drawbacks of the todays currency regulation system are revealed.

The steady tendency towards the outflow of currency values beyond Ukraine has been revealed through the non-return by their subjects of foreign economic relations in the course of export-import operations and the deterioration of the state of payments in the foreign currency in Ukraine. This is mostly due to the imperfection of the todays currency regulation system, which is normatively unregulated and ineffective.

A series of draft laws aimed to ensure the implementation of the unified state monetary policy, the free exercise of foreign exchange operations in the Ukrainian territory and the free movement of currency values in operations conducting between residents and nonresidents are considered.

The description of the basic legal acts, which form the basis of the new system of currency regulation is carried out.

The key innovations in the field of foreign exchange relations are highlighted, namely: abolition of currency supervision for exportimport operations up to $\mathbf{1 5 0}$ thousand UAH; Individual licenses for the foreign exchange transactions were canceled; abolished sanctions in the form of foreign economic activity termination; free accounts opening of the legal entities abroad; the deadline for settlement of export-import contracts up to $\mathbf{3 6 5}$ days has been increased; the limit on transfers abroad has been increased 10 times up to 150 thousand UAH per year without the opening of an account for individuals; the account operations of the legal non-residential entities in Ukrainian banks were simplified; the obligatory declaration for all values priced starting from 10 thousand EUR was unified.

The article emphasizes on the necessity of consistent currency liberalization, since its rapid realization can lead to the 
macroeconomic complications.

Keywords: currency regulation, currency legislation, currency

transactions, foreign economic relations, subjects of foreign economic activity.

Бондарева Т. Г., к.э.н., доцент (Национальный университет водного хозяйства и природопользования, г. Ровно), Немкович О. Б., к.э.н. (Обособленное структурное подразделение «Ровенский колледж Национального университета биоресурсов и природопользования Украины»г. Ровно)

\section{СОВРЕМЕННОЕ СОСТОЯНИЕ ПРАВОВОГО ОБЕСПЕЧЕНИЯ ОСУЩЕСТВЛЕНИЯ ВАЛЮТНЫХ ОПЕРАЦИЙ СУБЪЕКТОВ ВНЕШНЕЭКОНОМИЧЕСКОЙ ДЕЯТЕЛЬНОСТИ}

В статье раскрыты основные недостатки действующей системы валютного регулирования. Выявлено устойчивую тенденцию к оттоку валютных ценностей за пределы Украины из-за не возврата их субъектами внешнеэкономических отношений при осуществлении экспортно-импортных операций и ухудшение состояния расчетов в иностранной валюте в Украине. Представлена характеристика основных нормативно-правовых актов, которые ложатся в основу новой системы валютного регулирования. Выделены ключевые новации в сфере валютных отношений. Отмечена необходимость последовательного проведения валютной либерализации, поскольку быстрая ее реализация может привести к макроэкономическим осложнениям.

Ключевые слова: валютное регулирование, валютное законодательство, валютные операции, внешнеэкономические отношения, субъекты внешнеэкономической деятельности. 